\title{
RANCANG BANGUN KENDALI SUHU DAN KELEMBABAN PADA KUMBU JAMUR TIRAM BERBASIS ARDUINO MEGA 2560
}

\author{
Medilla Kusriyanto ${ }^{1}$, Warindi $^{2}$, Iyas Pandapotan Siregar ${ }^{3}$ \\ Jurusan Teknik Elektro, Fakultas Teknologi Industri, Universitas Islam Indonesia ${ }^{1,2,3)}$ \\ Jl. Kaliurang Km. 14,5 Sleman, Yogyakarta 55584 \\ E-Mail:medilla@uii.ac.id ${ }^{l}$
}

\begin{abstract}
Oyster mushroom is a food fungus with the general characteristics of the body of a white fruit to cream and the hood is semicircular shaped oyster shell with a slightly concave center. Nutritional content of oyster mushrooms are nutritious food ingredients with high protein content, rich in vitamins and minerals, low in carbohydrates, fats and calories. Oyster mushroom growth is strongly influenced by environmental conditions, especially temperature and humidity. In this research will be designed and built automatic temperature and humidity control system on oyster mushrooms to create the right environmental conditions on the cultivation of oyster mushrooms. It uses the DHT 11 sensor as a temperature and humidity sensor to be processed by an arduino mega 2560 microcontroller to condition the environment by watering, hotening and turning on the fan. The system also features data storage media temperature and humidity in the form of SD card and RTC real system for setting up timing of water oyster sprinkler. The results prove that the tool is made to function properly and can be developed as expected. The tool can maintain the temperature around $24^{\circ} \mathrm{C}-28^{\circ} \mathrm{C}$ and the humidity around $79 \%-87 \%$.
\end{abstract}

Keywords : Control, Temperature and Humidity, Oyster Mushroom Kits, DHT 11, Microcontroller, SD Card.

\section{PENDAHULUAN}

Jamur tiram secara alami tumbuh liar di hutan tropis. Di Indonesia terdapat banyak hutan tropis, sehingga jamur tiram memiliki potensi tumbuh dan berkembang dengan baik. Pertumbuhan jamur tiram sangat dipengaruhi oleh kondisi lingkungan sekitarnya. Produksi jamur tiram yang kurang maksimal disebabkan karena sulitnya menciptakan lingkungan yang sesuai, seperti panasnya di siang hari yang membuat suhu udara mencapai $\left( \pm 30^{\circ} \mathrm{C}\right)$ lebih dan malam hari yang membuat suhu udara mencapai $-\left( \pm 20^{\circ} \mathrm{C}\right)$. Pada dasarnya Jamur tiram dapat tumbuh dengan baik pada kisaran suhu $25-28{ }^{\circ} \mathrm{C}$ dan kelembaban 70 - $85 \%$. Pada umumnya jamur tiram dibudidayakan dalam kumbung (rumah jamur).

Kumbung berupa sebuah bangunan, yang diisi rak - rak untuk meletakkan baglog jamur tiram. Fungsi kumbung menjaga suhu dan kelembaban lingkungan jamur tiram. Agar mendapatkan suhu dan kelembaban yang ideal maka petani menyiram air dipermukaan tanah dan dinding kumbung jamur secara manual pada pagi dan sore hari. Cara ini tergolong membuat para petani banyak menghabiskan waktunya untuk menyiram dan memantau terus menerus kondisi suhu dan kelembaban pada kumbung.

\section{TINJAUAN PUSTAKA}

Faktor - faktor lingkungan yang menetukan pertumbuhan jamur tiram (Suriawiria, 2002) melakukan penelitian tentang factor - faktor lingkungan yang mempengaruhi pertumbuhan jamur tiram. Dari penelitiannya dihasilkan 2 parameter pokok yang berpengaruh terhadap pertumbuhan jamur yaitu suhu dan kelembaban. Pertumbuhan Miselia pada Substrat tanam pada suhu $23^{\circ}-29^{\circ} \mathrm{C}$ dengan kelembaban $70-100 \%$ dibutuhkan waktu 10-14 hari untuk tumbuh, sedangkan tubuh buah pada suhu $23^{0}-28^{0} \mathrm{C}$ dengan 
kelembaban 70 - $95 \%$ dibutuhkan waktu 3 -5 hari untuk tumbuh.

Optimization of himidifiying procedure in controlled environment for indoor cultivication of pleurotus pulmnarius (Islam $T$, Zakaria Z, Hamidin $N$ and Ishak, $M$, 2016) dalam penelitiannya menempatkan jamur tiram (Pleurotus Pulmonarius) dalam ruangan dengan suhu dan kelembaban yang dapat dikendalikan. Empat ventilasi dipasang dibagian atas untuk membawa udara dari dalam ke luar dan empat ventilasi kecil dipasang di dinding samping dan filter hitam untuk membawa udara dari luar ke dalam. Pengaturan dilakukan dengan metode pewaktuan untuk setiap ventilasi yang terdapat dalam sistem untuk mempertahankan kelembaban pada nilai tertentu.

Perancangan sistem pengendalian suhu dan kelembaban untuk budidaya jamur kuping (Gunawan, F, 2012) dalam penelitiannya membuat pengatur suhu dan kelembaban dengan menggunakan mikrokontroler ATMega 16. Pada penelitian ini akan dibuat sistem pengaturan suhu dan kelembaban kumbung pertumbuhan jamur tiram dengan menggunakan mikrokontroler arduino yang dilengkapi dengan LCD sebagai pembaca suhu dan kelembaban yang terintegrasi dengan media penyimpan data $S D$ Card. Sistem menggunakan sensor DHT 11 dan penampil berupa LCD touch screen. Sistem juga dapat melakukan pembacaan suhu dan kelembaban eksternal kumbung untuk melihat perbedaan suhu dan kelembaban dalam kumbung dan di luar kumbung.

\subsection{Arduino Mega 2560}

Arduino Mega2560 adalah papan mikrokontroler berbasiskan ATMega 2560. Arduino Mega 2560 memiliki 54 pin digital Input / Output, dimana 15 pin dapat digunakan sebagai output PWM, 16 pin sebagai Input Analog, dan 4 pin sebagai UART (Port Serial Hardware), $16 \mathrm{MHz}$ kristal osilator, koneksi USB, Jack Power, Header ICSP, dan tombol reset. Arduino Mega 2560 kompatibel dengan sebagian besar shield yang dirancang untuk Arduino Duemilanove atau Arduino Diecimila. Arduino Mega 2560 adalah versi terbaru yang menggantikan versi Arduino Mega.

\subsection{Sensor DHT 11}

Sensor DHT11 adalah sensor digital yang dapat mengukur suhu dan kelembaban udara disekitarnya. Sensor ini sangat mudah digunakan bersama dengan Arduino. Memiliki tingkat stabilitas yang sangat baik serta fitur kalibrasi yang sangat akurat. Koefisien kalibrasi disimpan dalam OTP program memory, sehingga ketika internal sensor mendeteksi sesuatu, maka modul ini menyertakan koefisien tersebut dalam kalkulasinya. DHT11 termasuk sensor yang memiliki kualitas terbaik, dinilai dari respon, pembacaan data yang cepat, dan kemampuan anti - interference.

\subsection{Relay}

Relay adalah saklar yang dioperasikan secara elektrik dan merupakan komponen elektromekanikal yang terdiri dari 2 bagian utama yakni Elektromagnet (Coil) dan Mekanikal (seperangkat kontak saklar). Relay menggunakan perinsip Elektromagnetik untuk menggerakan kontak saklar sehingga dengan arus listrik yang kecil dapat menghantarkan listrik yang bertegangan lebih tinggi. Pada penelitan ini relay digunakan sebagai antarmuka antara keluaran mikrokontroler Arduino dengan level tegangan 5 volt ke level tegangan yang lebih tinggi untuk menghidupkan kipas dan lampu pada kumbung.

\subsection{Modul LCD}

Modul LCD sebuah liquid crystal atau perangkat elektronik yang dapat digunakan untuk menampilkan angka atau teks. Ukuran pixel 320 x 480 dengan ukuran layar 3.2" dan dilengkapi built-in SD Card reader yang digunakan untuk data logger. LCD ini diprogram dengan bantuan Library LCDUTFT. 


\subsection{Modul RTC}

Real - time clock DS3231 adalah IC yang dibuat oleh perusahaan Dallas maxim yang menyediakan informasi waktu secara persis mulai dari detik, menit, jam, tanggal, hari, bulan sampai dengan tahun. RTC ini di akses dengan menggunakan komunikasi I2C dan di program dengan Library RTCLib.

\subsection{Kumbung Jamur Tiram}

Dinding kotak kumbung jamur tiram dibuat dengan menggunakan papan triplek dari kotak kumbung dan kayu segi empat untuk pondasi. Adapun ukuran untuk pembuatan kotak kumbung jamur tiram ditunjukkan pada gambar 1 .

Untuk membuat sebuah kotak kumbung jamur membutuhkan 5 buah papan triplek yang berukuran panjang $30 \mathrm{~cm}$, lebar $30 \mathrm{~cm}$ dan lebar $30 \mathrm{~cm}$, semua ukuran dibuat sama agar mempermudah pembuatan kotak. Pondasi kotak jamur membutuhkan 12 buah kayu segi empat yang berbeda ukuran, 8 buah kayu segi empat berukuran $28 \mathrm{~cm}$ untuk lebar atas dan bawah kotak dan 4 buah lagi untuk pondasi berdiri berukuran panjang $25 \mathrm{~cm}$. Hasil dari pembuatan kotak kumbung jamur tiram dengan menggunakan triplek dan kayu segiempat ditunjukkan pada gambar 2 .

\section{METODOLOGI PENELITIAN}

Secara umum sistem pengendali suhu dan kelembaban pada kumbung jamur tiram berbasis mikrokontroller arduino dan terintegrasi dengan data logger ditunjukkan pada blok diagram gambar 3 .

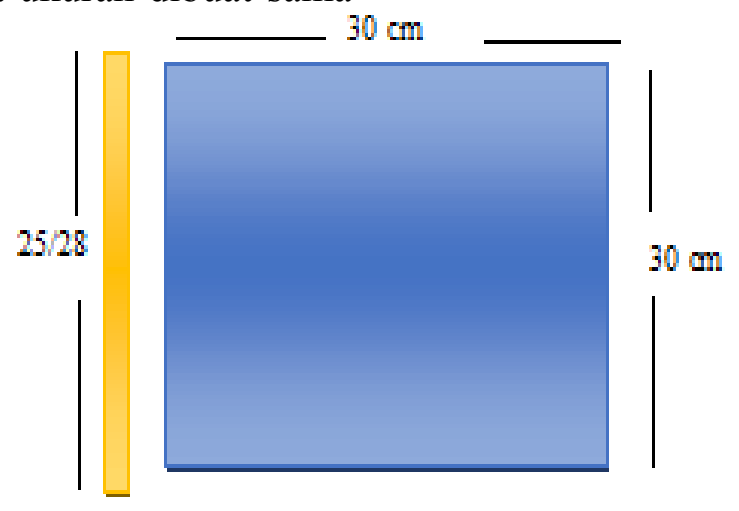

Gambar 1. Ukuran Kotak Kumbung Jamur Tiram.

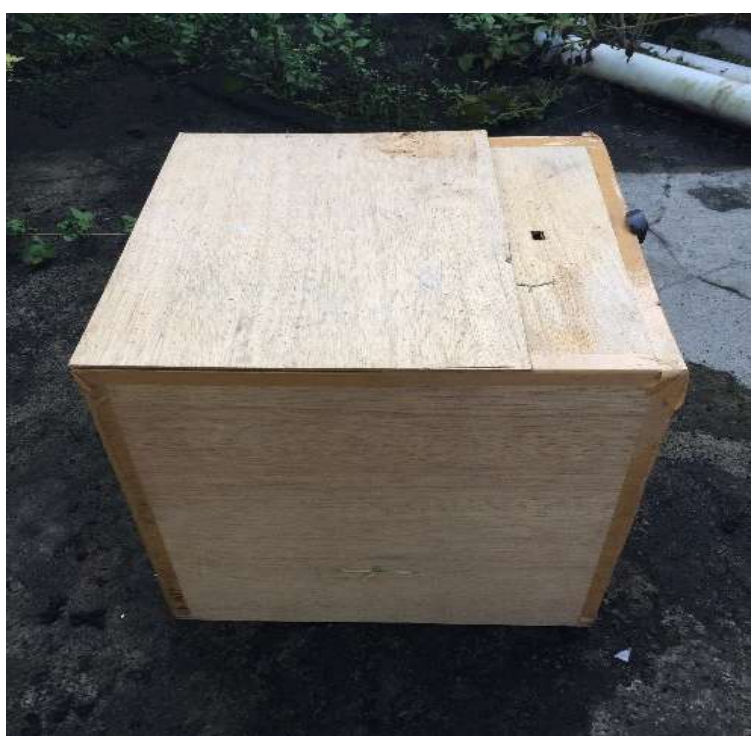

Gambar 2. Kotak Kumbung Jamur Tiram. 
Sensor DHT 11 akan membaca suhu dan kelembaban kumbung jamur tiram yang akan diolah oleh arduino mega 2560 untuk mengaktifkan lampu atau kipas pada kumbung untuk mengatur suhu dan kelembaban media tumbuh jamur tiram dengan memberi logika pada masukan relay. Suhu dan kelembaban bisa diamati dengan membaca nilai yang tertera pada penampil LCD.

Data tanggal, bulan, tahun, hari serta waktu yang dibaca dari RTC akan dijadikan pewaktu dalam penyimpanan data suhu dan kelembaban pada kumbung jamur tiram yang akan disimpan pada media penyimpan berupa SD Card.

\subsection{Rangkaian Sensor DHT 11 dan Arduino Mega 2560}

Perancangan sistem ini pin A0 pada Arduino mega 2560 dihubungkan ke sensor DHT11 agar Arduino mega 2560 dapat menerima data suhu dan kelembaban kumbung jamur tiram agar dapat meng instruksikan modul relay untuk mengaktifkan dan nonaktifkan pompa air, lampu pijar dan kipas DC.

\subsection{Rangkaian RTC Dengan Arduino}

Di perancangan ini pin SCL dan SDA pada Arduino mega 2560 dihubungkan ke RTC (Real Time Clock) untuk waktu penyiraman dipagi hari dan sore hari. Bentuk rangkaian ditunjukkan pada gambar 5 .

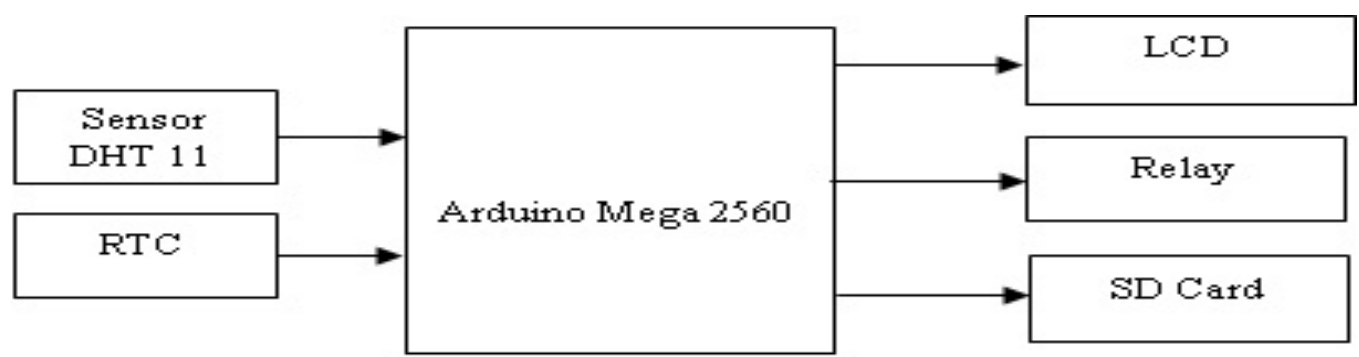

Gambar 3. Blok Diagram Sistem.

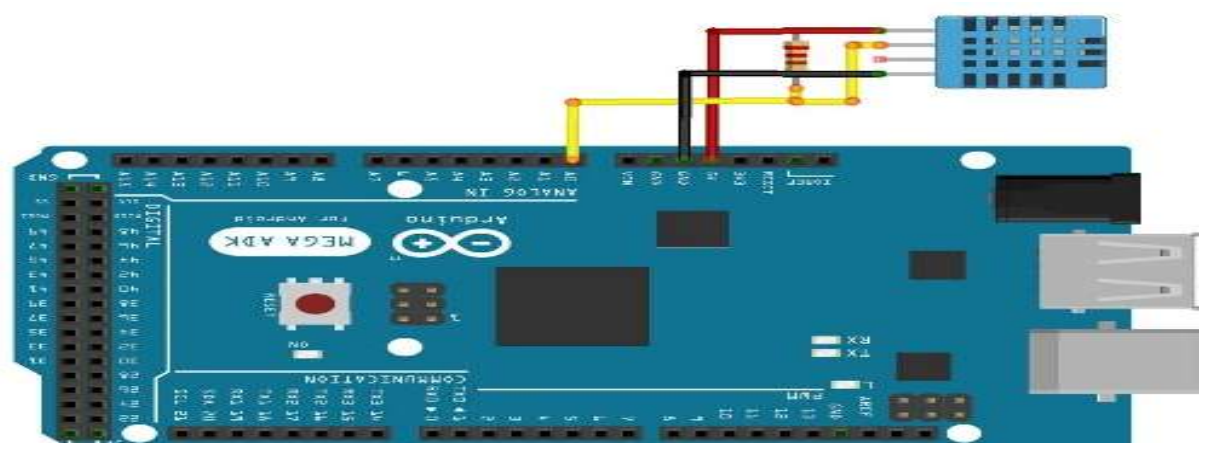

Gambar 4. Rangkaian Sensor DHT 11 Dengan Arduino Mega 2560.

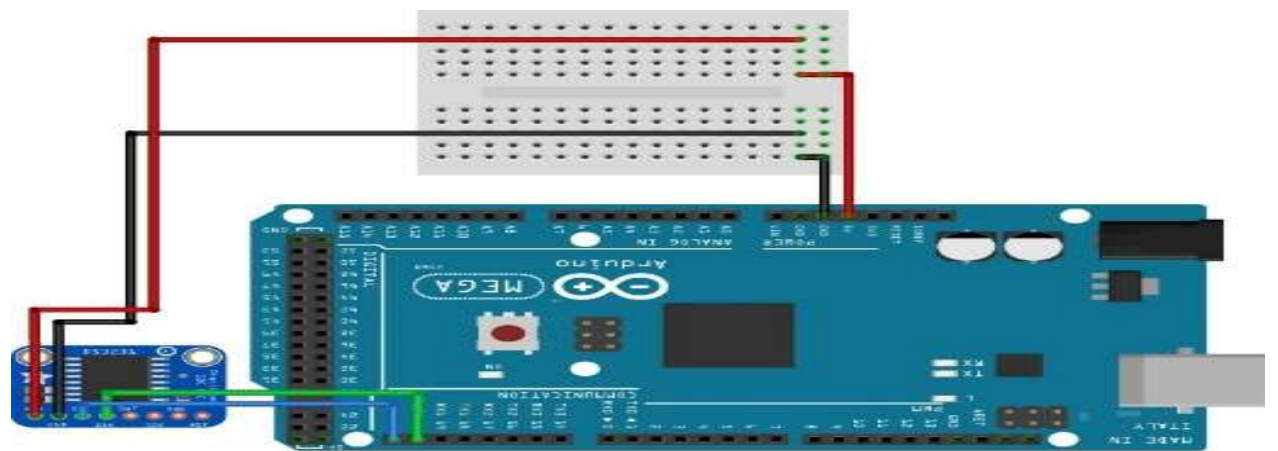

Gambar 5. Rangkaian RTC dan Arduino Mega 2560. 


\subsection{Rangkaian Relay dan Arduino Mega 2560}

Di perancangan ini pin $\mathrm{A} 1$, pin $\mathrm{A} 2$ dan pin A3 pada Arduino mega 2560 dihubungkan ke modul relay agar dapat menginstruksikan modul relay sesuai dengan suhu dan kelembaban dikumbung jamur tiram. Pemasangan rangkaian relay dengan arduino mega 2560 ditunjukkan pada gambar 6 .
4. HASIL DAN PEMBAHASAN

\subsection{Pengujian Pembacaan Suhu} Kumbung Jamur Tiram

Pembacaan suhu pada penelitian ini dilakukan dengan 2 perlakuan jenis pengaturan yaitu pengaturan secara otomatis dengan menggunakan arduino mega 2560 dan sensor suhu DHT 11 dan pengaturan seacara manual. Hasil pembacaan suhu ditunjukkan pada gambar 7 .

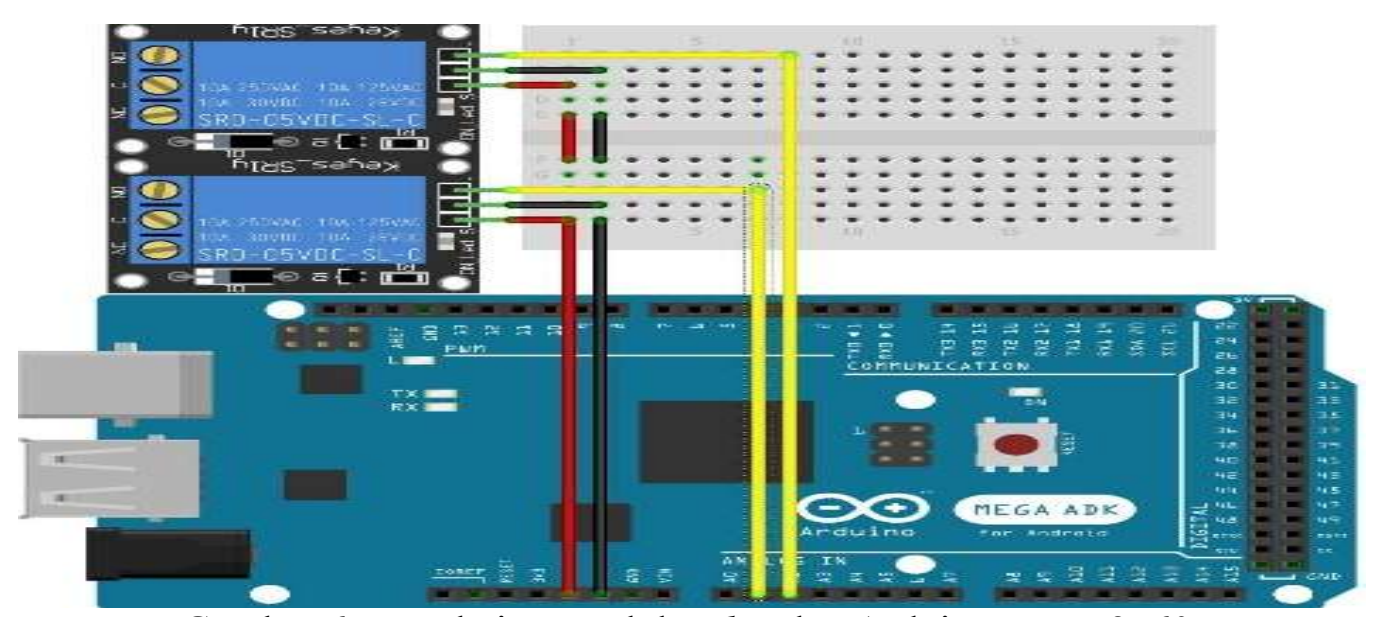

Gambar 6. Rangkaian Modul Relay dan Arduino Mega 2560.

\section{Hasil perbandingan suhu}

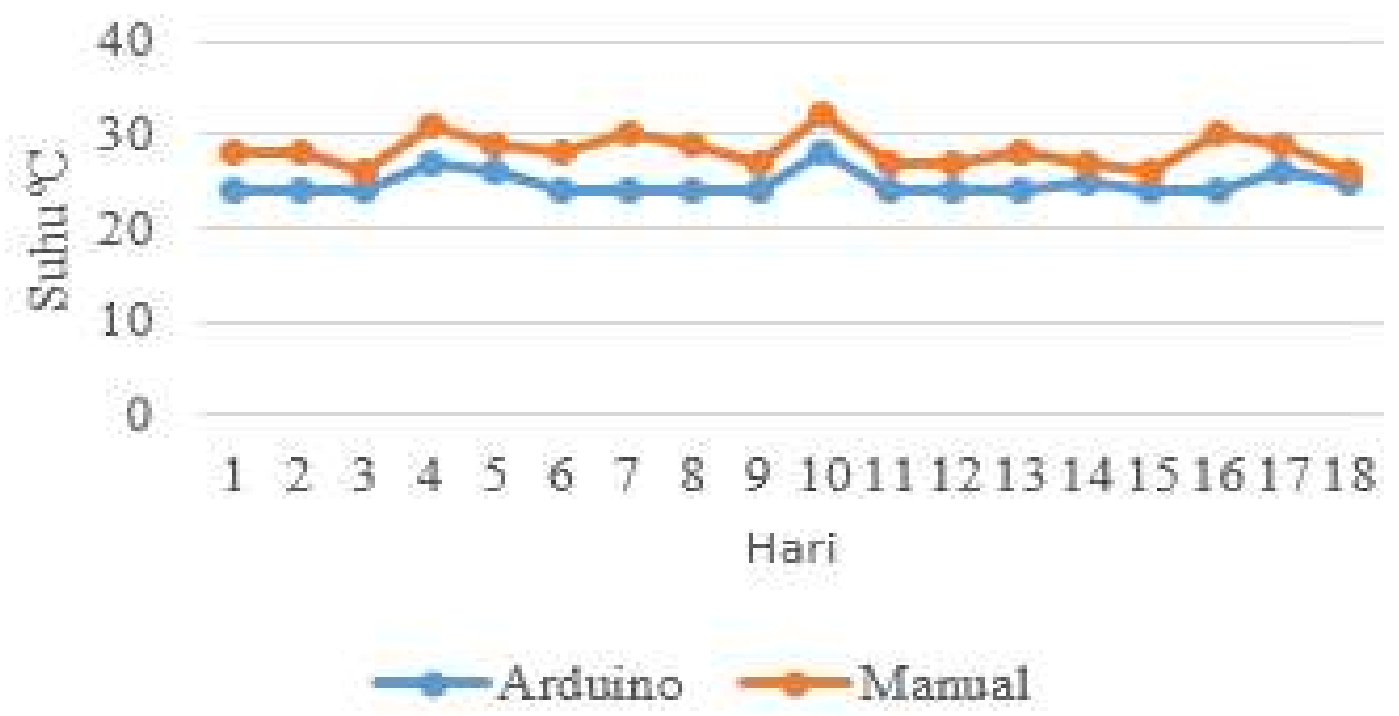

Gambar 7. Pembacaan Suhu Kumbung yang Diatur Secara Otomatis dan Manual. 
Suhu ideal jamur tiram untuk tumbuh adalah $25^{\circ} \mathrm{C}-28^{\circ} \mathrm{C}$. Dari data yang disajikan pada gambar 7 dapat dilihat bahwa nilai suhu maksimal pada kumbung jamur tiram yang terkendali menggunakan Arduino mega 2560 adalah $28^{\circ} \mathrm{C}$ dan nilai suhu minimalnya adalah $24^{\circ} \mathrm{C}$ dengan perubahan suhu rata rata 3,89\%. Rentang suhu ini adalah rentang suhu yang cukup bagus bagi jamur tiram untuk tumbuh karena tidak melebihi nilai batas maksimal dari suhu yang dibutuhkan jamur tiram untuk tumbuh. Nilai suhu maksimal kumbung jamur tiram yang terkendali manual didapat sebesar $32^{\circ} \mathrm{C}$ dan nilai suhu terendahnya adalah $26^{\circ} \mathrm{C}$ dengan perubahan suhu rata - rata sebesar $4,9 \%$. Nilai suhu ini kurang bagus untuk pertumbuhan jamur tiram karena batas atas yang melampaui nilai tumbuh ideal dari jamur tiram $\left(4^{0} \mathrm{C}\right)$.

\subsection{Pengujian Pembacaan Kelembaban Kumbung Jamur Tiram}

Pembacaan kelembaban pada penelitian ini dilakukan dengan 2 perlakuan jenis pengaturan yaitu pengaturan secara otomatis dengan menggunakan Arduino mega 2560 dan sensor suhu DHT 11 dan pengaturan secara manual. Hasil pembacaan kelembaban ditunjukkan pada gambar 8 .

Kelembaban ideal jamur tiram untuk tumbuh adalah $70 \%$ - $85 \%$. Dari data gambar 4.2. ditunjukkan pembacaan kelembaban pada kumbung jamur tiram yang diatur secara otomatis diperoleh nilai kelembaban minimal kumbung adalah 79\% dan nilai kelembaban maksimal kumbung adalah $87 \%$ dengan perubahan rata - rata kelembaban adalah 1,5\%. Nilai kelembaban dengan pengaturan manual didapat nilai kelembaban minimal sebesar $67 \%$ dan nilai kelembaban maksimalnya adalah $83 \%$ dengan rata - rata perubahan kelembaban sebesar $4,68 \%$.

\subsection{Pengujian Penyimpanan Data Pada SD Card}

Pengujian dilakukan dengan membaca data yang tersimpan pada $S D$ Card dengan menggunakan aplikasi bawaan windows notepad. Hasil pengujian ditunjukkan pada gambar 9.

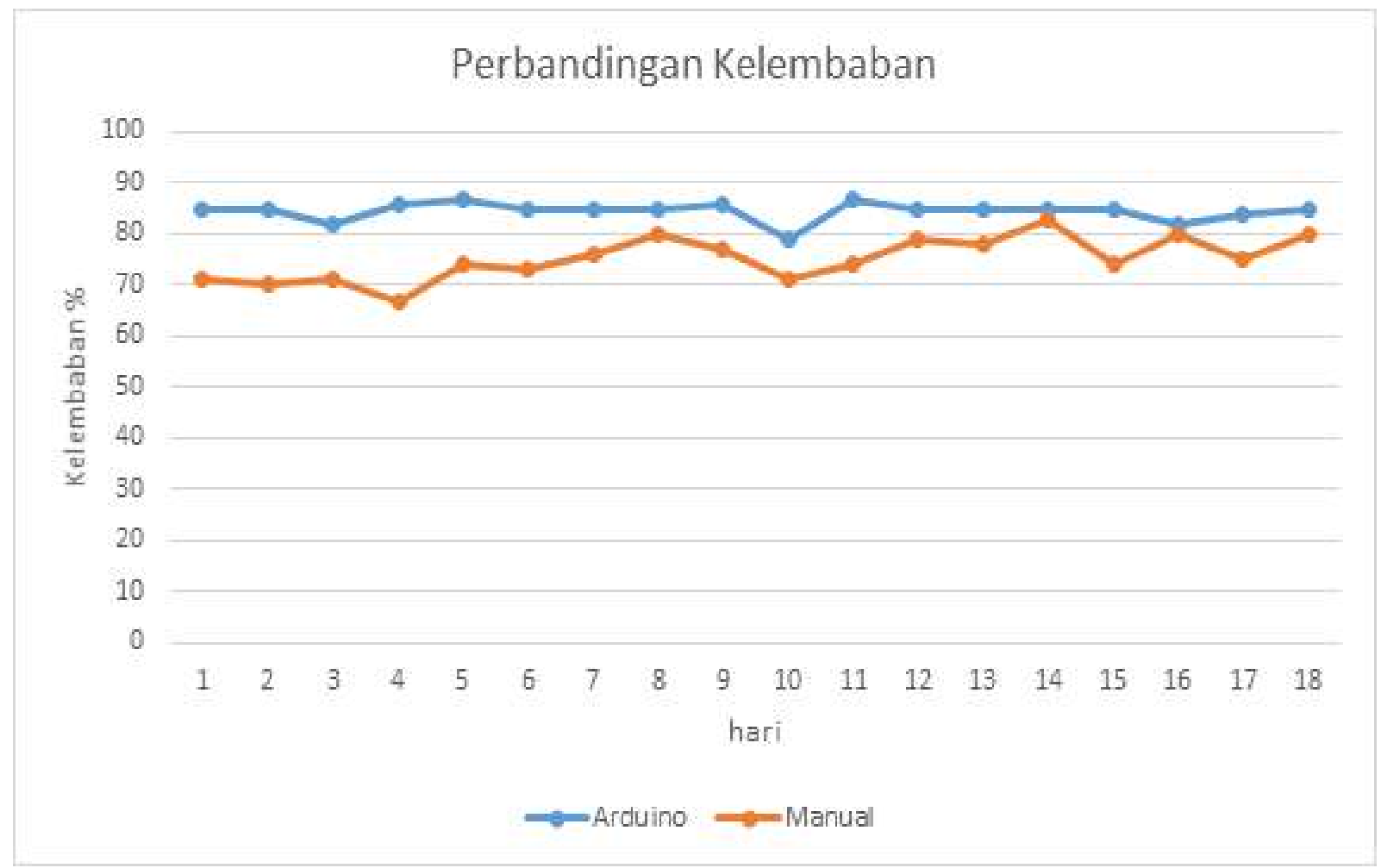

Gambar 8. Pembacaan Kelembaban Secara Otomatis dan Manual. 
Tabel 1. Pengamatan Pertumbuhan Jamur Tiram

\begin{tabular}{|c|c|c|}
\hline Hari Ke & $\begin{array}{c}\text { Pertumbuhan Jamur tiram dengan } \\
\text { kumbung terkendali arduino }\end{array}$ & $\begin{array}{c}\text { Pertumbuhan Jamur tiram dengan } \\
\text { kumbung terkendali manual }\end{array}$ \\
\hline 1 & & \\
\hline 2 & & \\
\hline 3 & & \\
\hline 4 & & \\
\hline
\end{tabular}

\begin{tabular}{|c|c|c|}
\hline \multicolumn{3}{|c|}{ arduino - Notepad } \\
\hline Edit & Format & View \\
\hline blower & Mati & 85.80 \\
\hline blower & Mati & 85.00 \\
\hline blower & Mati & 85.00 \\
\hline blower & Mati & 85.00 \\
\hline blower & Mati & 85.00 \\
\hline blower & Mati & 85.00 \\
\hline blower & Mati & 85.00 \\
\hline blower & Mati & 85.00 \\
\hline blower & Mati & 85.00 \\
\hline blower & Mati & 85.00 \\
\hline blower & Mati & 85.00 \\
\hline blower & Mati & 85.00 \\
\hline blower & Mati & 85.00 \\
\hline blower & Mati & 85.00 \\
\hline blower & Mati & 85.00 \\
\hline blower & Mati & 85.00 \\
\hline blower & Mati & 85.00 \\
\hline blower & Mati & 85.00 \\
\hline blower & Mati & 85.80 \\
\hline blower & Mati & 85.00 \\
\hline blower & Mati & 85.00 \\
\hline blower & Mati & 85.00 \\
\hline blower & Mati & 85.00 \\
\hline blower & Mati & 85.00 \\
\hline blower & Matí & 85.00 \\
\hline
\end{tabular}

\begin{tabular}{|c|c|}
\hline 24 & $08=44=16$ \\
\hline 24 & $88: 45: 16$ \\
\hline 24 & $88: 46: 16$ \\
\hline 24 & $88: 47: 17$ \\
\hline 24 & $88: 48: 17$ \\
\hline 24 & $88: 49: 17$ \\
\hline 24 & $\theta 8=5 \theta=18$ \\
\hline 24 & $\theta 8: 51=18$ \\
\hline 24 & $\theta 8=52: 19$ \\
\hline 24 & $08: 53=19$ \\
\hline 24 & $88: 54: 19$ \\
\hline 24 & $\theta 8: 55: 2 \theta$ \\
\hline 24 & $\theta 8: 56: 2 \theta$ \\
\hline 24 & $\theta 8: 57: 2 \theta$ \\
\hline 24 & $88=58=21$ \\
\hline 24 & $88: 59: 21$ \\
\hline 24 & $\theta 9: \theta \theta: 21$ \\
\hline 24 & $89: 81: 22$ \\
\hline 24 & $09: 82: 22$ \\
\hline 24 & $\theta 9: \theta 3: 22$ \\
\hline 24 & $\theta 9: 84: 23$ \\
\hline 24 & $89: 05: 23$ \\
\hline 24 & $\theta 9: 06: 23$ \\
\hline 24 & $\theta 9: 87: 24$ \\
\hline 24 & $\theta 9: \theta 8: 24$ \\
\hline
\end{tabular}

\begin{tabular}{|c|c|}
\hline 04.01 .2017 & \\
\hline 04.01 .2017 & \\
\hline 4.01 .2017 & \\
\hline 04.01 .2017 & \\
\hline 84.81 .2017 & \\
\hline 4.01 .2017 & \\
\hline 04.81 .2017 & \\
\hline 4.81 .2017 & \\
\hline 11.2817 & \\
\hline 01.2017 & \\
\hline 11.26 & \\
\hline 1.26 & \\
\hline $04.01 .201 \mathrm{~J}$ & \\
\hline 04.01 .2011 & \\
\hline 4.81 .2017 & \\
\hline 04.81 .2017 & \\
\hline 04.01 .26 & \\
\hline 217 & \\
\hline 01.2017 & \\
\hline 04.01 .2017 & \\
\hline 04.81 .2017 & \\
\hline 01.2017 & \\
\hline 04.01 .2017 & \\
\hline 04.01 .2017 & \\
\hline 9901291 & \\
\hline
\end{tabular}

口

$\times$

Gambar 9. Hasil Pengujian Pentimpanan Data pada SD Card. 
Dari gambar 9 dapat diketahui bahwa sistem penyimpanan data pada SD Card dapat bekerja sesuai dengan fungsinya.

\subsection{Pengujian Pertumbuhan Jamur Tiram}

Pengujian dilakukan dengan mengamati pertumbuhan jamur tiram dalam periode waktu tertentu. Dalam penelitian ini disajikan pengamatan pertumbuhan jamur dalam waktu 4 hari. Hasil pengamatan disajikan pada tabel 1. Dari data yang disajikan pada tabel 1 dapat dilihat bahwa pertumbuhan jamur tiram dalam kumbung dengan suhu dan kelembaban yang dikendalikan dengan arduino memiliki pertumbuhan yang lebih baik dibandingkan dengan pertumbuhan jamur dalam kumbung yang dikendalikan secara manual. Hal ini ditunjukkan pada hari ketiga pertumbuhan tunas jamur lebih bagus bila dibandingkan dengan jamur tiram dalam kumbung manual.

\section{KESIMPULAN}

Dari hasil percobaan dan analisis dapat diambil kesimpulan bahwa sistem dapat mengendalikan suhu ruangan kumbung dengan nilai suhu antara $24^{0} \mathrm{C}-28^{\circ} \mathrm{C}$ dengan rata - rata perubahan suhu sebesar 3,89\% dan dapat mengatur kelembaban ruangan kumbung dengan rentang kelembaban $79 \%$ $87 \%$ dengan rata - rata perubahan kelembaban sebesar 1,5\%. Dari pengamatan pertumbuhan jamur tiram dalam kumbung yang terkendali arduino lebih bagus pertumbuhannya bila dibandingkan dengan kumbung yang terkendali manual. Hal ini ditunjukkan bahwa pada hari ke 3, jamur yang dibudidayakan pada kumbung yang dikendalikan dengan arduino sudah tumbuh tunas jamurnya. Sistem juga berhasil menyimpan data suhu dan kelembaban ke media penyimpan berupa SD Card.

\section{DAFTAR PUSTAKA}

Gunawan, F., 2012. Perancangan Sistem Pengendalian Suhu Dan Kelembaban untuk Budidaya Jamur Kuping. Jurnal penelitian. Universitas sebelas maret, Juni.

Islam, T, Zakaria, Z, Hamidin, N and Ishak, M., 2016, Optimization of Humidifiying Procedure In Controlled Environment for Indoor Cultivication of Pleurotus Pulmnarius, African Journal of Biotechnology, vol 15.

Suriawiria., 2002, Faktor - Faktor Lingkungan Yang Menetukan Pertumbuhan Jamur Tiram, Yogyakarta. 